\title{
Indium In 111 Pertuzumab
}

National Cancer Institute

\section{Source}

National Cancer Institute. Indium In 111 Pertuzumab. NCI Thesaurus. Code C105808.

A radioimmunoconjug ate composed of a humanized recombinant monoclonal antibody directed against the extracellular dimerization domain of the tyrosine kinase receptor human epidermal growth factor-2 (HER-2) and linked to the gamma-emitting radioisotope indium In 111, with potential use in radioimag ing. Upon administration, indium In 111 pertuzumab binds to HER-2. After binding and internalization into HER-2expressing tumor cells, radioactive In 111 facilitates the detection of HER-2-expressing tumor cells using single photon emission computed tomography (SPECT). This may predict or evaluate the tumor's response to certain HER-2-targeting chemotherapeutics. 